УДК 537.632 .3

\title{
Synthesis, Morphology, and Visible Magnetic Circular dichroism of Ni-C nanoparticles
}

\author{
Dmitriy A. Petrov* \\ Ruslan D. Ivantsov ${ }^{\dagger}$ \\ Kirensky Institute of Physics SB RAS \\ Akademgorodok, 50/38, Krasnoyarsk, 660036 \\ Russia \\ Sergey M. Zharkov ${ }^{\ddagger}$ \\ Kirensky Institute of Physics SB RAS \\ Akademgorodok, 50/38, Krasnoyarsk, 660036 \\ Siberian Federal University \\ Svobodny, 79, Krasnoyarsk, 660041 \\ Russia \\ Chun-Rong Lin ${ }^{\S}$ \\ Fu-Ren Shu \\ Yaw-Teng Tseng \\ National Pingtung University \\ Pingtung City, Pingtung County, 90003
}

Taiwan

Received 10.09.2016, received in revised form 10.10.2016, accepted 12.11.2016

Ni-C nanoparticles powder (NP) was synthesized using high-temperature pyrolysis of nickel nitrate in an organic solvent. The NP was characterized by transmission electron microscopy (TEM), energy dispersive $x$-ray spectroscopy (EDXS) and selected-area electron diffraction (SAED). Structural characterization of the samples confirmed the formation of small, medium and large Ni nanoparticles with face-centered cubic structure (fcc) and enlarged lattice parameter. Magnetic circular dichroism (MCD) of samples with different mean particle sizes showed a red shift with decrease of mean particle size.

Keywords: Ni-C, nanoparticles, MCD, TEM.

DOI: 10.17516/1997-1397-2016-9-4-481-484.

\section{Preparation}

Ni-C NP was prepared using high-temperature pyrolysis of nickel nitrate in an organic solvent. In the typical process, $4 \mathrm{mmol}$ nickel (II) nitrate $\left[\mathrm{Ni}\left(\mathrm{NO}_{3}\right)_{2} \cdot 6 \mathrm{H}_{2} \mathrm{O}\right]$ was dissolved in a mixture solution of $10-\mathrm{ml}$ oleylamine and $20-\mathrm{ml}$ oleic acid in a three-neck flask equipped with an inlet of argon gas, condenser, magnetic stirrer, thermocouple, and heating mantle. All chemicals and

\footnotetext{
*irbiz@iph.krasn.ru

†ird@iph.krasn.ru

$\ddagger_{\text {zharkov@iph.krasn.ru }}$

$\S$ crlin@mail.nptu.edu.tw

(C) Siberian Federal University. All rights reserved
} 
solvents are used as received. After the argon gas was introduced into the system for $10 \mathrm{~min}$, the mixture was heated to $240^{\circ} \mathrm{C}$ and maintained at this temperature for $1 \mathrm{hr}$. It took $\sim 50 \mathrm{~min}$ to heat the reaction system to boiling at $360^{\circ} \mathrm{C}$. After this temperature remained for $1 \mathrm{hr}$, it started to increase steadily. After reaching $\sim 380^{\circ} \mathrm{C}$, the reaction solution burst out to form dense gas clouds and black products, accompanying a fast increase in temperature up to $395^{\circ} \mathrm{C}$. The reaction temperature then fell down instantly and dwelled at $140^{\circ} \mathrm{C}$ for $1 \mathrm{hr}$ before removing heating mantle for cooling. With the addition of hexane, the black precipitates were magnetically separated for several times and stored in hexane for further studies.

\section{Samples Morphology}

Microstructure and phase composition of the NP were investigated by TEM and EDXS using a transmission electron microscope $200 \mathrm{kV}$ JEOL JEM-2100 $\left(\mathrm{LaB}_{6}\right)$.

Using the TEM, three typical sizes of Ni-C nanoparticles were revealed (Figs. 1, 2): small $(\sim 5 \mathrm{~nm})$, medium $(20-30 \mathrm{~nm})$ and large $(50-200 \mathrm{~nm})$ particles. The elemental composition was determined by EDXS supports the presence of nickel. The set of diffraction reflections (Fig. 3) in the SAED pattern corresponds to the Ni fcc structure 17\% enlarged cell parameter. A similar large increase of lattice parameter was observed in Ref. [1].

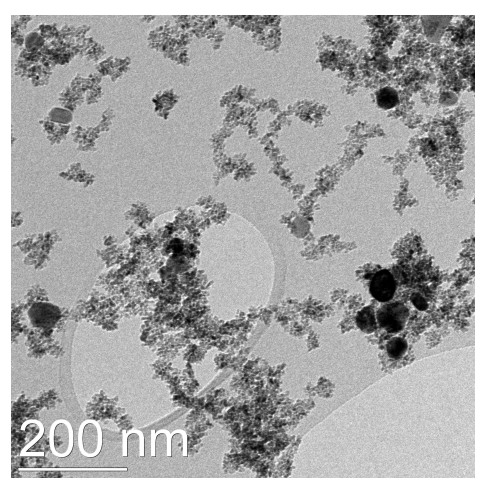

Fig. 1. The TEM of Ni-C NP

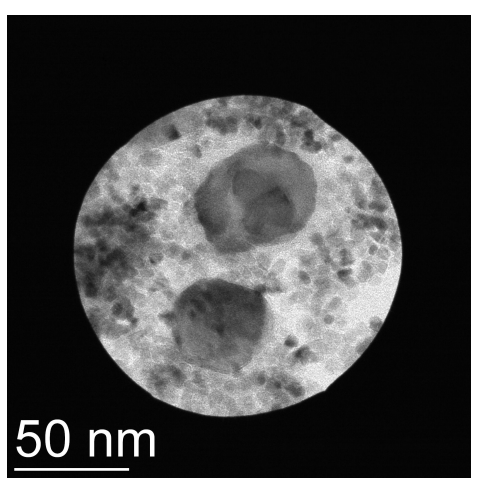

Fig. 2. The TEM of Ni-C NP with higher magnification

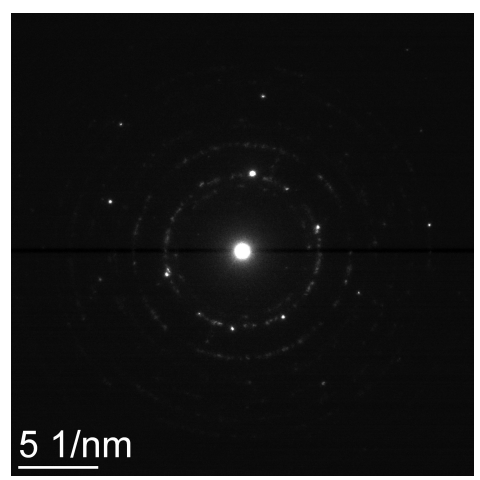

Fig. 3. The set of diffraction reflections

\section{Magnetic Circular Dichroism}

To investigate the MCD, Ni-C NP were dried and four samples were prepared. The first sample was prepared by mixing of NP with silicone matrix (all particles). Further, NP was placed in an alcohol for the flotation. Then the test-tube was agitated. After 5 min (small and medium) and 20 min precipitation (small) the top layer was taken from the tube and then was dried on the glass. It is worth noting that the terms "small", "medium" and "large" are conventional and do not preclude a finding of large particles in the "small" samples. The procedure was repeated many times. Thereafter particles also were placed in the silicon matrix. The fourth sample was prepared like the last sample but was not mixed with silicon.

MCD was measured in the normal geometry: the magnetic vector and the light beam were 
directed normal to the sample plane. The MCD value was measured in the spectral range $1.2-$ $3.5 \mathrm{eV}$ in the magnetic field $3 \mathrm{kOe}$ at room temperature.

The Fig. 4 shows the normalized MCD spectra for Ni-C nanoparticles and Ni thin film $(\sim 20 \mathrm{~nm})$. MCD spectra of Ni-C nanoparticles change a sign in the range 1.6-2.25 eV and have the minimum at energy lower $1.5 \mathrm{eV}$. It is seen that decrease in the mean particle size leads to a red shift of the MCD spectra. The high density of nanoparticles dried on the glass led the spectrum of the nanoparticles to be closer to the spectrum of Ni thin film than to the spectrum of small particles in the silicon matrix.

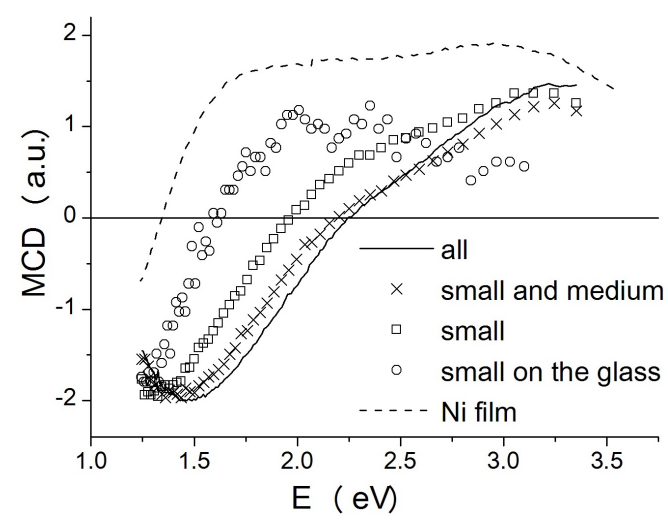

Fig. 4. The MCD spectra of Ni-C nanoparticles and Ni thin film

The MCD spectrum for small Ni-C nanoparticles in the silicon matrix is in a fairly agreement with data on the off-diagonal component of the conductivity tensor for bulk nickel derived from the first-principles calculation based on density-functional theory, Ref. [2]. In this Reference, the $\mathrm{Ni}$ band structure was calculated taking into account the contribution of matrix elements originated from $\mathrm{p}-\mathrm{p}$ and $\mathrm{d}-\mathrm{d}$ transitions in spin-orbit interaction.

\section{Conclusion}

The Ni-C nanoparticles powder prepared by high-temperature pyrolysis of nickel nitrate in an organic solvent was investigated. The powder consists of small ( $5 \mathrm{~nm})$, medium $(20-30 \mathrm{~nm})$ and large (50-200 nm) nickel particles with fcc structure and the $17 \%$ enlarged lattice constant. Nanoparticles, presumably coated with carbon. MCD spectra of the nanoparticles differ from the spectrum of thin nickel film but similar to that they demonstrate the red shift with decreasing the average particle size. Increasing of the concentration of the nanoparticles plays a more significant role in the approximation of the nanoparticles MCD spectrum to the MCD spectrum of the film than the particle size.

This work was supported by the RFBR grant 14-02-01211 and MOST 102-2112-M-153-002$M Y 3$.

\section{References}

[1] A.S.Bolokang, M.J.Phasha, Solid-state transformation in ball milled nickel powder, Materials Letters, 64(2010), 1894-1897. 
[2] N.Mainkar, D.A.Browne, J.Callaway, First-principles LCGO calculation of the magnetooptical properties of nickel and iron, Physical Review B, 53(1996), no. 7, 3692-3701.

\section{Синтез, морфология и видимый МКД наночастиц Ni-C}

\section{Дмитрий А. Петров}

Руслан Д. Иванцов

Сергей М. Жарков

Институт физики им. Л.В.Киренского СО РАН

Академгородок, 50/38, Красноярск, 660036

Россия

Чун-Ронг Лин

Фу-Рен Шу

Йау-Тенг Цзенг

\footnotetext{
Порошок наночастич, $\mathrm{Ni}$ - $\mathrm{C}$ был синтезирован с помощъю высокотемпературного пиролиза нитрата никеля в органическом растворителе. Наночастищы были исследованы с помощью просвечивающей электронной микроскопии, энергодисперсионной рентгеновской спектроскопии и дифракции электронов выбранной зоны. Структурная характеризация образцов подтвердила образование маленьких, средних и больших наночастии, никеля с гранецентрированной кубической структурой $u$ увеличенным параметром решётки.Магнитный круговой дихроизм образцов с различными средними размерами частии, показал красное смещение при уменъшении среднего размера частии.

Ключевые слова: $\mathrm{Ni-C,} \mathrm{наночастицы,} \mathrm{МКД,} \mathrm{электронная} \mathrm{микроскопия.}$
} 